\title{
LOSS OF STRENGTH OF ROCKS UNDER THE INFLUENCE OF MICROWAVES
}

\author{
Raia Sultanalieva, Ainur Konushbaeva
}
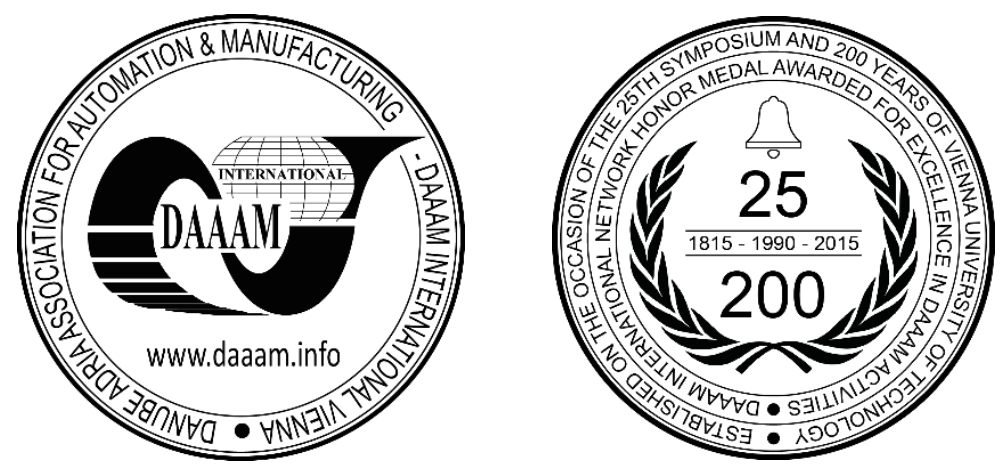

This Publication has to be referred as: Sultanalieva, R[aia] \& Konushbaeva, A[inur] (2018). Loss of Strength of Rocks Under the Influence of Microwaves, Proceedings of the 29th DAAAM International Symposium, pp.1026-1031, B. Katalinic (Ed.), Published by DAAAM International, ISBN 978-3-902734-20-4, ISSN 1726-9679, Vienna, Austria DOI: $10.2507 / 29$ th.daaam.proceedings.146

\begin{abstract}
One of the main tasks of mining science is the development of new technologies for mining and enrichment, allowing to reduce material and energy costs and loss of mineral resources. For the development of modern technologies of mineral processing requires the full use of knowledge about the physical properties and processes occurring in rocks, as well as the ability to manage the properties of rocks. In mineral processing, to recover metals and mineral components, processes of crushing and milling involved a large amount of hard comminuted ores and minerals. It is known that ores of non-ferrous, rare and noble metals mainly have high strength. Using these traditional methods of ore grinding leads to increased energy consumption, increased wear of metal parts of the mill, to significant losses of recoverable metals. In this regard, the need to develop methods and means of purposeful change of the technological properties of the grinding of mineral raw materials is difficult to ensure efficient processing of a stimulus of new studies. This paper proposed a method of softening hard optimum ores and minerals, which allows to save energy during grinding, increasing the useful component output (the metal being recovered) by acting on the rocks microwave electromagnetic waves.
\end{abstract}

Keywords: mechanical grinding of ore; method of softening; mineral grains; impact to the ore microwaves

\section{Introduction}

In the process of ore preparation, mechanical grinding of ore, necessary for further flotation, is the most energyintensive and expensive process in the technological chain of extraction of useful components (metals, useful minerals). In this case, the mechanical grinding process efficiency is $5-10 \%$, the remainder attached for breaking (generation of a new surface) ore energy is dissipated in the form of dissipative losses (heat energy, sound, ambient vibrations medium). Therefore, of great practical interest is the development of new ways of destruction or weakening of ores and minerals, new energy and resource ores grinding technologies [6].

The impact of electric, electromagnetic fields on rocks leads to a change in their mechanical properties, the formation and change of structural residual stresses at the boundaries and inside the grains, disruption of structural bonds, leading to the weakening of strong ores and minerals. 
Prospects for the use of purposeful changes in the mechanical properties of rocks in the extraction of metals from ores technology defined understanding of the physical nature regularities and mechanisms converting processes structural state polymineral aggregate initiated by external action. Knowledge of these patterns allows you to choose a rational type and mode of physical processing of mineral raw materials, providing economic benefits, efficiency and ecological purity of production. Traditional consideration of the physical processes occurring in rocks, in homogeneous environment does not disclose properties of gear changes under external influence. Only new approaches that take into account the heterogeneity of rocks and an understanding of the mechanism and causes of structural transformations of ores and minerals that occur when exposed to physical fields, allow for a significant reduction in energy intensity of the high-cost grinding process [6].

The large amount of experimental data indicates that the properties of rocks plunge physical effects vary in a wide range. In the general case, a change in the parameters that quantitatively describe the properties of the rock occurs nonmonotonically; different types and effects cause changes that differ in nature; changes in properties caused by the action of physical fields on rocks are prone to relaxation and depend not only on the intensity, but also on the duration and other parameters characterizing the physical treatment regimes.

It should be noted that the rock at their study considered collectively as genetic differences with inherent features and developments like objects, characterized by their physical state of the complex and technical parameters. Particular attention is given to the mechanical strength of rock as a parameter characteristic of the majority of the destruction of rocks.

The analysis of methods of influence on rocks and minerals by physical fields shows that, in most cases, losses of recoverable metals, useful minerals, i.e. low percentage of their extraction from ores, the result of the discrepancy between the capabilities of the technological solutions and technical means used by the variety of physical and technical parameters involved in the processing of ores.

Currently known mechanical, physico-chemical, thermal, thermomechanical and other methods of destruction of rocks. When mechanical methods in the rocks, stresses are created that exceed their ultimate strength. In thermal methods, the destruction of rocks occurs due to the occurrence of thermal stresses in them and various kinds of effects (dehydration, dissociation, melting, evaporation, etc.). In thermomechanical methods, thermal action is carried out purposefully to preliminarily reduce the resistance of the rock to subsequent mechanical destruction. Chemical (physico-chemical) methods of rock destruction involve the use of highly active chemicals [10].

From non-traditional types of effects on ores and minerals to increase the efficiency of enrichment, intensive ultrasound, heat, RF and microwave electromagnet treatments were tested [11]. From the considered impacts highfrequency electromagnetic treatment, due to the large volume and the efficiency of the nature of the impact, is the most appropriate.

Despite the wide range of physical fields used for the destruction of rocks and taking into account the main features of this process discussed above, it can be concluded that it is impossible to create a universal method of destruction suitable for all types and varieties of rocks. Therefore, we can speak only of selecting the optimal for a specific method for breaking rock providing resource in subsequent processing.

Finding effective ways of breaking hard rock based on the achievements of technical physics, electrical engineering and electronics has allowed creating the electrical methods of destruction. These methods are based on the absorption of electrical energy supplied to the rock and its subsequent transformations, as a result of which the rock is destroyed or its strength is reduced. The distinction used for the impact of sources of electrical energy in solving various technological problems has led to the development of several areas based on the use of direct current and power frequency, high voltage electrical pulses, high frequency electromagnetic energy (RF) and ultra-high frequency (UHF) radiation, infrared radiation and optical ranges, etc. [4]. However, this is not considered ores inhomogeneity and anisotropy of rock-forming minerals, which did not allow to identify the optimal parameters of the external physical impacts $[11,12,13]$. The advantages of softening in microwave electromagnetic fields include:

- the volumetric nature of the conversion of radiated microwave energy into heat within the depth of penetration, depending on the frequency of the electromagnetic field;

- high heating temperature, allowing to ensure the rate of softening, commensurate with the accepted rates of mechanical loading [12].

In this regard, the study of grinding processes of rocks and ores, in order to control their strength properties, by affecting them with microwave electromagnetic waves is an important task.

\subsection{Materials and Methods.}

To fracture the rock, and preparing them for enrichment apply thermal, effects of RF and microwave electromagnetic waves. The microwave field ore-containing metallic minerals absorb microwave energy waves so ore minerals are heated. The uneven heating leads to the appearance of thermo-mechanical stresses and the formation of micro cracks, and the formation of residual stresses, which in turn also causes a change in resistance [1]. For targeted changes in mechanical properties of rock impacts applied microwave electromagnetic field and heat treatment. The object of the study was the rocks, ores, selected from different ore deposits in Kyrgyzstan.

It should be noted that the duration of exposure to microwaves determines not only the effect of softening and hardening, but also the magnitude of energy consumed. 
For the studies, the required number of samples are selected from the ore deposit, are manufactured sample size of 20-25 mm. To obtain the average value of the coefficient strength and specific energy of grinding is made at time intervals of 5 measurements of microwave exposure at one and the same sample species.

The coefficients of the fortress are determined on a special device POK (device for determining the strength), consisting of a tubular headframe, a meter of the fines fraction. Each individual sample is crushed in a glass of a vertical tubular scraper, a POK device, a $2.4 \mathrm{~kg}$ weight, dropped from a height of $600 \mathrm{~mm}$. If it is necessary to change the magnitude of the work of destruction during the pounding, it is advisable to vary the number of impacts of the falling weight on the sample.

The weight of the weight and the height of its dropping should be kept constant. The resulting fines after pounding copra poured from the beaker onto a sieve with openings of $0.5 \mathrm{~mm}$ and sieved. Fraction size smaller than $0.5 \mathrm{~mm}$ (passing through a sieve of that size) is collected and poured in a glass of $23 \mathrm{~mm}$ diameter piston meter, with which is determined by the height of the column of this dusty fraction. The quantity coefficient of the fortress investigated the rock is calculated in relation to the work expended newly formed surface by the empirical formula M.M. Protodyakonov [5]:

$$
f_{T}=\frac{20 n}{l}
$$

where $\boldsymbol{n}$ - is the number of impacts of a free falling load on one hinge;

$\boldsymbol{l}$ - the height of the dust column in the meter, mm;

Research has established that the surface newly formed during crushing of a brittle material consists mainly (approximately by $90 \%$ ) of the surface of the smallest pieces of size less than $0.5 \mathrm{~mm}$. Therefore, to significantly simplify the method after crushing, the surface of only small fractions - less than $0.5 \mathrm{~mm}$ - is determined — that is, the height of the dust column in the meter is proportional to the newly formed surface of the pieces obtained during crushing [5].

Initially, the initial values of the coefficient of the fortress and the specific-volume energy intensity of ore grinding are determined by the method of pounding. Then, the same samples from ores are exposed to microwave waves in a microwave oven. Samples of ores in batches of 200-250 g and average sizes of 20-25 mm are placed inside the furnace and subjected to microwave irradiation.

The mode of exposure in the oven ranges from 1 minute to 9 minutes. In the furnace, the electricity conducted by the magnetron is used to generate microwave energy. The microwaves penetrate the target area through the openings within a furnace, and can not penetrate through the metal wall of the furnace.

Power to the furnace was $-700 \mathrm{~W}$, microwave frequency - $2450 \mathrm{MHz}$. The useful volume of the furnace is $0.03 \mathrm{~m}^{3}$. Next it is determined the specific energy of grinding for the initial state (unexposed to radiation), and for different times of exposure to microwaves. In this case, the optimal values of the exposure time of the microwave waves are determined, which correspond to the minimum value of the specific energy intensity of grinding of this ore [8].

The optimum values of exposure time for receiving microwaves whole ore processing of this type and size of the pieces to be ground in a production environment. As can be seen from figures 1, 2, 3, 4, the optimal time of exposure to microwave waves for limestone (Ak-Tatyr open-pit mine, Batken oblast), diorite (Toktozan deposit), gray phillite (Kumtor mine) is 3 minutes, and for quartz (Vostochny mine Kounrad) - 5 minutes.

Below is the experimentally determined dependence of the specific energy consumption of different grinding ores from different deposits.

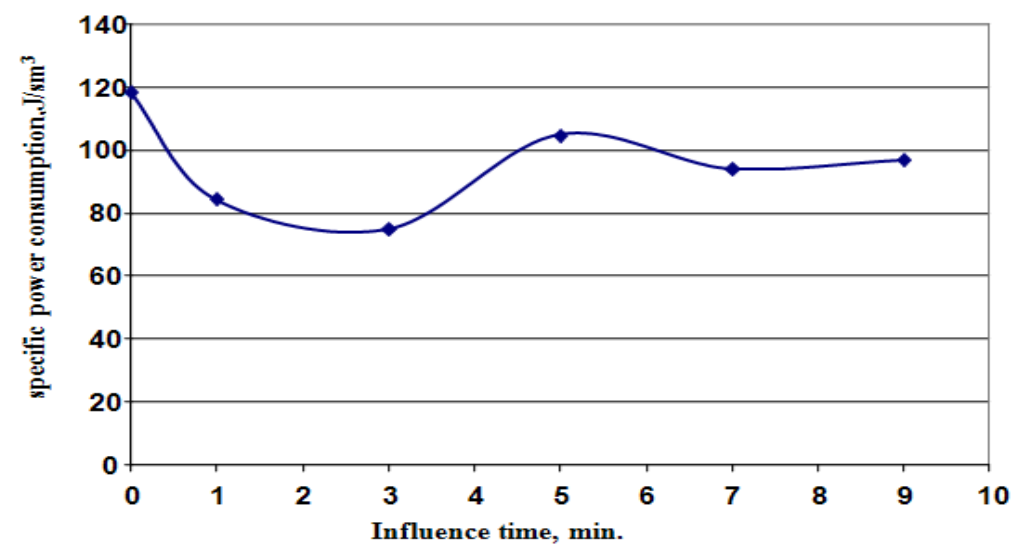

Fig. 1. Dependence specific power consumption crushing from influnce time SHF waves (limestone, deposit Ak-Tatyr). 


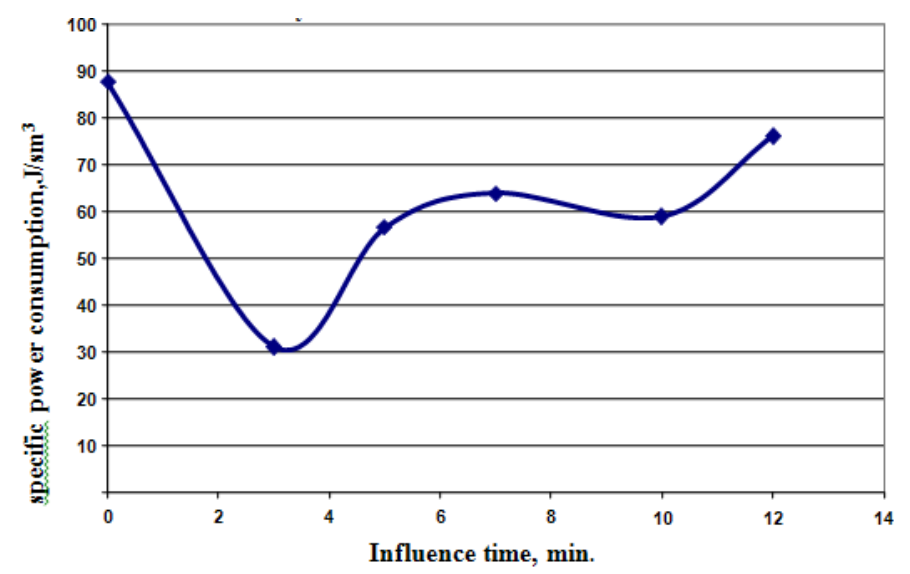

Fig. 2. The dependence oft he specific volumetric energy grinding diorite deposits. Toktozan the time of action of microwaves.

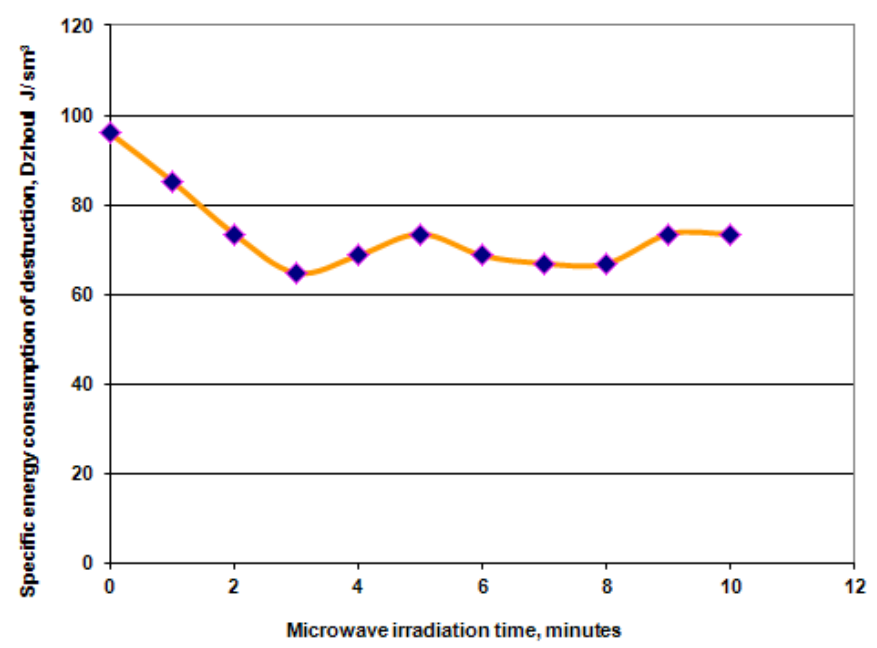

Fig. 3. A plot of specific energy consumption of destruction from the time of microwave irradiation (gray Phyllite,

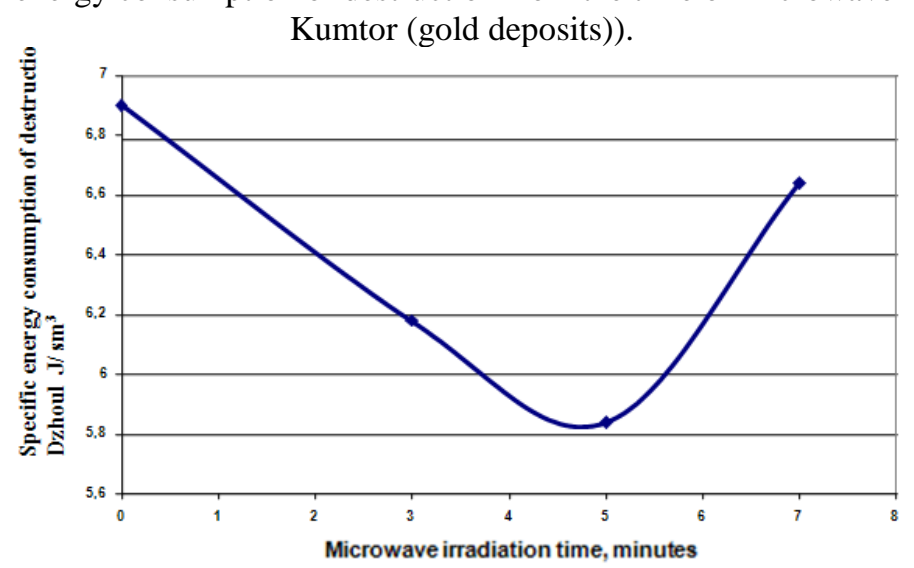

Fig. 4. The dependence of the specific volumetric energy milling quartz (East-Kounrad, samples \#7, PK298 +50) on the exposure time of microwaves.

Energy savings on grinding with prior exposure to microwaves should not only offset the energy consumption for heating in the microwave pre-exposure, but also provide significant energy savings. Judging by the reduction in strength it can be noted that the reduced wear of metal parts of the crusher, respectively, decreases energy consumption and grinding out useful components increases.

Below, Table 1 shows the results of the analytical and experimental determination of the values of specific energy consumption for shredding various exposure durations microwaves ore and mineral. As can be seen from the table, the deviation of the calculated data on the specific energy consumption of grinding from the experimental values is on average $5-10 \%$. 


\begin{tabular}{|c|c|c|c|c|}
\hline \multirow{2}{*}{$\begin{array}{l}\text { Name and place of } \\
\text { selection of rock, } \\
\text { mineral }\end{array}$} & \multirow{2}{*}{$\begin{array}{l}\text { Duration of radiation of } \\
\text { microwave waves in } \\
\text { minutes }\end{array}$} & \multicolumn{2}{|c|}{$\begin{array}{l}\text { The specific energy consumption of } \\
\text { grinding, Joule/cm3 }\end{array}$} & \multirow[t]{2}{*}{$\begin{array}{l}\text { Deviation of } \\
\text { calculated values } \\
\text { from experimental,\% }\end{array}$} \\
\hline & & $\begin{array}{l}\text { Experimental } \\
\text { value }\end{array}$ & Estimated value & \\
\hline $\begin{array}{l}\text { Dark gray Phyllite, } \\
\text { Kumtor }\end{array}$ & $\begin{array}{l}0 \text { (initial) } \\
1 \\
2 \\
3 \\
4 \\
5 \\
6 \\
7 \\
8\end{array}$ & $\begin{array}{l}97 \\
85 \\
72 \\
63 \\
69 \\
74 \\
68 \\
67 \\
67\end{array}$ & $\begin{array}{l}97 \\
89.6 \\
75.9 \\
66.4 \\
79.2 \\
73.5 \\
69 \\
65.4 \\
62.3\end{array}$ & $\begin{array}{c}0 \\
5.1 \\
5.1 \\
5.1 \\
9.1 \\
0.7 \\
1.4 \\
2.4 \\
7.5\end{array}$ \\
\hline Quartz, East Kounrad & $\begin{array}{l}0 \text { (initial) } \\
1 \\
2 \\
3 \\
4 \\
5 \\
6 \\
7\end{array}$ & $\begin{array}{l}69 \\
66.7 \\
64.1 \\
61.9 \\
59.3 \\
58.2 \\
61.8 \\
66.3\end{array}$ & $\begin{array}{l}69 \\
63.9 \\
60 \\
57.1 \\
54.8 \\
53.2 \\
63.5 \\
62.5\end{array}$ & $\begin{array}{c}0 \\
4.4 \\
6.4 \\
8.4 \\
8.2 \\
9.4 \\
2.7 \\
6.1\end{array}$ \\
\hline $\begin{array}{l}\text { Limestone, } \\
\text { Ak-Tatyr }\end{array}$ & $\begin{array}{l}0 \\
1 \\
2 \\
3 \\
5 \\
7 \\
9\end{array}$ & $\begin{array}{l}118 \\
84 \\
76 \\
74.6 \\
104.5 \\
93.8 \\
96.9\end{array}$ & $\begin{array}{l}118 \\
103 \\
87.2 \\
76.6 \\
94 \\
97 \\
76\end{array}$ & $\begin{array}{c}0 \\
22.6 \\
14.7 \\
2.6 \\
10 \\
3.4 \\
21.6\end{array}$ \\
\hline Diorite, Toktozan & $\begin{array}{l}0 \\
1 \\
2 \\
3 \\
4 \\
5 \\
6 \\
7\end{array}$ & $\begin{array}{l}88 \\
72 \\
45 \\
32 \\
43 \\
57 \\
62 \\
64\end{array}$ & $\begin{array}{l}88 \\
74 \\
58 \\
42 \\
44 \\
61 \\
57 \\
54\end{array}$ & $\begin{array}{c}0 \\
2.8 \\
28.9 \\
31 \\
2.3 \\
7 \\
8 \\
15.6\end{array}$ \\
\hline
\end{tabular}

Table 1. The experimental and calculated values of the specific energy consumption for shredding various exposure durations of microwaves.

From the results of experimental and analytical studies it can be seen that at the optimal time of exposure to microwave waves (3-5 minutes) there is a significant decrease in the energy intensity of ore grinding. This provides significant savings in energy costs. It should be noted that the greater the heterogeneity of the ore, the greater the effect of softening and energy savings during grinding.

\section{Conclusion}

1. From all known and to a certain extent studied types of energy, the most promising energy is the electromagnetic field of the microwave (UHF) range. The advantage of softening in microwave electromagnetic fields is the volumetric nature of the influence of microwave energy on the structural state of ores.

2. Microwave irradiation allows to increase the degree of detection of grains and thereby, simultaneously reducing the strength, increases the yield of the useful component.

3. Energy savings on grinding with prior exposure to microwaves should not only offset the energy consumption for heating in the microwave pre-exposure, but also provide significant energy savings. 
4. The optimal time ( 3 to 5) minutes exposure to microwaves and this characteristic of the rock formation temperature at which realizes efficient comminution of ores and minerals, their power consumption is achieved by at least milling.

5. Research will continue at the Kyrgyz State Technical University. I. Razzakov, work is underway to determine and influence other physicomechanical parameters on the mechanism of destruction of strong rocks.

\section{Acknowledgments}

I thank my colleagues from the department for their help in preparing this article

\section{References}

[1] Москалев А.Н. и др. Способ разрушения горных пород электромагнитными волнами. Авт. св. СССР № 724731, кл. E21C 37/18, 1977г.). Moskalev A.N., etc. the Way of destruction of rocks electromagnetic waves. Patent of USSR № 724731, E21C 37/18, 1977).

[2] Абкин Е.Б. и др. Измельчение руд с применением электромагнитной энергии СВЧ. Обогащение руд. Ленинград, 1986, № 6, с 2-5. Abkin E.B., etc. Crushing of ores with application of electromagnetic energy Ultrahigh frequencies. Enrichment of ores. Leningrad, 1986, № 6, pp. 2-5.

[3] Новик Г.Я., Зильбершмидт М.Г. Управление свойствами пород в процессах горного производства. М., Недра, 1994. Novik G. JA, Zilberschmidt M.G. Management of rock properties in mining processes. M, Nedra, 1994.

[4] Зецер Ю.И. и др. Применение СВЧ - нагрева для рудоподготовки железистых кварцитов Михайловского горно-обогатительного комбината перед их обогащением. //Всес. VI научно-практич. конф. "Применение СВЧ-энергии в технологич. процессах и научных исследованиях". Тезисы докл., Саратов, 1991, -с. 98-100. Zetser J.I., etc. Application of Ultrahigh frequencies -for heating for ore preparation ferruterous quartzites of Mihajlovsky mountain-concentrating combine before their enrichment. // VI scientifically-practical conference "MICROWAVE ENERGY application in technology processes and scientific researches". Theses report Saratov, 1991, - pp. 98-100.

[5] Ильницкая Е.И., Тедер Р.И., Ватолин Е.С., Кунтыш М.Ф. Свойства горных пород и методы их определения. -М.: Недра. -1969. - 452 с. Ilnitskaja E.I., Teder R. I, Vatolin E.S., Kuntysh M. F. Properties of rocks and methods of their definition. M.: Nedra.-1969. - 452 p.

[6] Султаналиева Р.М. Принципы целенаправленного изменения механических свойств руд и минералов. Монография. г.Бишкек. 2014. Sultanaliev R.M. Principles of targeted changes in the mechanical properties of ores and minerals. Monograph. Bishkek. 2014

[7] Соловьев В.И. Взаимодействие мощных СВЧ-полей с рудными породами различного состава. - М.: Обогащение руд, 2001, № 2.- C.13-14. Soloviev V.I. The interaction of powerful microwave fields with ore rocks of different composition. - M .: Enrichment of ores, 2001, № 2.- P.13-14.

[8] Султаналиева Р.М., Тажибаев К.Т., Аналитическое описание изменения энергоемкости измельчения руд от длительности воздействия СВЧ волн. Международный научный журнал «Инновационная наука», г.Уфа, Россия,10/2015 с.-244-247. Sultanalieva R.M., Tazhibaev KT, Analytical description of the change in the energy intensity of ore grinding due to the duration of exposure to microwave waves. International scientific journal "Innovation Science", Ufa, Russia, 10/2015 pp.-244-247.

[9] Диденко, Б.В. Зверев А.Н. СВЧ - энергетика / М.: Наука, 2000. Didenko, B.V. Zverev A.N. Microwave Energy / M .: Science, 2000.

[10] Султаналиева Р.М. О способе измельчения крепких руд. // Вестник №5 (111) КазНТУ им. К.И.Сатпаева, г. Алматы, 2015, с.336-342. R. Sultanaliyeva About the method of grinding strong ores. // Bulletin number 5 (111) KazNTU them. K.I. Satpayev, Almaty, 2015, p. 366-342.

[11] Максименко А.Г., Уваров А.П. Исследование комбинированного СВЧ - механического воздействия на горные породы // Всес. У1 научно-практич. конф. "Применение СВЧ энергии в технологич. процессах и научных исследованиях". Саратов, 1991, С. 71-73. Maksimenko A.G., Uvarov A.P. Study of the combined microwave - mechanical effects on rocks // Vses. U1 scientific and practical. conf. "The use of microwave energy in technological processes and scientific research." Saratov, 1991, pp. 71-73.

[12] Образцов А.П. Исследование эффекта объемного разрушения горных пород в сильных СВЧ-полях. Киев, Наукова думка, 1976, С. 149-150. Obraztsov A.P. Investigation of the effect of bulk destruction of rocks in strong microwave fields. Kiev, Naukova Dumka, 1976, p. 149-150.

[13] Петров В.M. Новые применения радиоэлектроники: разупрочнение горных пород мощным электромагнитным полем СВЧ . // Информост. 2002. Petrov V.M. New applications of radio electronics: the softening of rocks by a powerful electromagnetic microwave field. // Informost. 2002

[14] Rebrisoreanu Mircea Traian Ion, Pencea Ion, Dumitrescu Ioan, Traista Eugen, Nimara Ciprian \& Postolache Mihaela. New convolutional approach of estimation of incertainty of compressive strength test results on some rocks. Annals of DAAAM for 2010 \& Proceedings of the 21st International DAAAM Symposium, Volume 21, No. 1, ISSN 1726-9679, ISBN 978-3-901509-73-5, Editor B. Katalinic, Published by DAAAM International, Vienna, Austria, EU, 2010 